\title{
Depiction of Indian Society in Kamala Markandaya's Handful of Rice
}

\author{
Dr. J. Ranjithkumar
}

Assistant Professor, Department of English, Hindusthan Institute of Technology.Coimbatore, Tamilnadu-641032. India

\begin{abstract}
Markandayais the most outstanding woman novelist of the Indian English novelists' belonging to both the east and west. India is the country of her birth and upbringing. England is that of her adoption. She lived for sometimes in south India to get the first-hand experience from the rural life. A thorough study of her novels shows that a gradual evolution of maturity is there in her art and genius. Her novels cover a wide range of themes. The study of Markandaya's novels shows a gradual evolution of her art and craft. Omniscient narration, first person narration, the character narrating the story, the flash back techniques, simple but effective conversational style, inclusion of myths from India-these are powerfully employed in her novels. Before her marriage and setting down in England. She spent some years in a South Indian Village and thus gained firsthand knowledge of Indian rural life. In her other novels as well as in A Handful of Rice we come across the real and vivid picture of Indian society. The novels of Kamala Markandaya give us ample proof not only of her talent, but also her crusading sprit for the welfare of humanity. From her tragic vision wells the pity and concern for mankind that keeps seeking truth, goodness and beauty even though human ideals are not everlasting and this concern is manifested in her works. Kamala Markandaya makes her novels the forum for her sensitive cries against suffering caused by various things like poverty, industrialization and social tension. We may easily study this description under the following heads:
\end{abstract}

Keywords-Hunger, Poverty, Rice, Starvation, Society, Unemployment.

\section{INTRODUCTION}

She is an Indian English novelist. The major themes: Poverty, hunger, starvation, the east-west encounter, cultural conflict, freedom struggles, dislocation of rural life, religious tradition, the after-math effects of freedom and modernization are important and recurrent themes of her novels. The recurrent themes are: Indian womanhood, the sufferings of women, the love between two different sects of people, the sacrifice of love, man and woman relationships, the religious beliefs and the rational outlook- these are other themes which are clearly exploited by the writer.

\section{POVERTY}

Poverty is the keynote of Indian village life. Most of the people in Indian village are poor as the village do not offer any opportunity to the people to earn a better livelihood. In the villages " they had all lived between bouts of genteel and acute poverty- the kind in which the weakest went to the wall, the old ones andthe babies, dying of tuberculosis, dysentery line the 'falling fever', 'recurrent fever'. People in village live below poverty line. "He(Ravi) knew better the economics of village life, knew the superhuman efforts, the begging and the borrowing that went into raising the train fare, the money for the extras demanded by pride and the standards of a city. His father had managed it once, where many men like him never managed it at all.

Coming to the city, Ravi is disillusioned that for a poor man there is no difference between a city and village. An illiterate or under-educated villager is only suitable for manual labour. Here he is again exploited. Ravi and Apu get 80 rupeesfor one dozen jackets while the shop-owners sell one jacket for 125 rupees. Ravi becomes very angry at this, "he and his like perennially scratching round for a living, while they sat still and waved fat on huge peremptory margins." Ravi has to give up all his ambitions and after Apu's death his economic condition worsens. Finally, we find him struggling for a handful of rice. In want of money Apu and Ravi's son, Raju, are not properly cured and both of them die. She brings real reforms in the living condition of the poor, untouchables, the poor peasants, the coolies and the oppressed members of the 
society to restore them to human dignity and inculcate selfawareness.

\section{HUNGER}

Poverty gives birth to hunger and starvation. In our daily life, we may easily find people begging for a handful of rice, flour or any foodstuff. In the very beginning of the novel when the hero is before us, he is very hungry. He goes to Apu's house and says, "I'm hungry, I want a meal. I'm starving." Ravi's friend, Damodar's stomach is lean and curved inward. All he wants is a meal. Fruits are rarity for Ravi and Apu's family. In the village as well as in the city we may see "a cluster of people around the ice-fruit stand, mostly children without the money to buy, who stand transfixed like small worshippers in front of the row of coloured syrup bottles."

After Apu's death, Ravihas to sell many things from the house just to satisfy his and his family's hunger. It is to satisfy his hunger that he leaves his village, comes to the city and indulges himself in petty criminal activities and afterward works very hard in Apu's house, first as his assistant and later as his successor. But even then he is unable to live a better life.

\section{UNEMPLOYMENT}

Unemployment is one of the burning problems of our country. When Ravi comes to the city and is acquainted with the hard realities of the city he thinks, "if there had been a job, it might have been different, but there was no job. The city was full of graduates -the college turned them out in their thousands each year- looking for employment, so what chance had he, with his meagre elementary school learning?" "Sometimes he despised them, these refined young men who were having their education slapped back in their faces" and sometimes "pitted against men fresh from the colleges, bearing the seal of these great institutes of learning. And these young men waged as fierce a competition as any he had known. He had seen the queues that every vacancy produced, the long waiting times, the fine-drawn patience that suddenly shaped these mild, well-bred men into screaming agitators."

Another burning problem of our country is rapidly growing population and consequently the problem of accommodation is also taking place. In the beginning we see that the protagonist, Ravi, "had no quarters...it was a matter of chance where he slept. A bench in the park, an empty six-by-two space in a doorway, the veranda of an empty house, the pavement, all in turn had served to bed down on.... since he had left the railway station, the coffee house and its pavement frontage had become a second house to him."

When Ravi first goes inside Apu's house he feels that an army has encamped in the house. After his marriage with Nalini they have to share their room with others. They have no privacy. Ravi has an ardent ambition to have a separate shelter for them, "a place they could call their own where he and his wife could talk, plan, dream, and make love undisturbed." Soon, his dream is fulfilled; he constructs a shelter on the roof of the house. But after some time their privacy is disturbed. Thangam, Nalini's sister often comes there to share their room.

The problem of growing population is also directly discussed in the novel. When Nalini is going to have a child, according to their tradition, Jayamma sends Ravi out of the house. Outside the house, he meets a man and both are indulged in conversation. Ravi comes to know that the man has many children. Ravi says that it is his own fault; he should not have had so many children. Now the man also realizes the fact and says, "one's easy two's easy, three and four one can manage- but when they keep coming - sometimes I tell you, brother, I want to put my hands round their necks and squeeze until I know I'll never again have to think about feeding them, no, never again hear again hear them whimper."

Ravi also has many brother and sisters. Apu has a large family and in time Nalinigives birth to four children. One of them dies. Thangam also has many children.

\section{TYPICAL SCENES OF INDIAN LIFE}

The novel is replete with typical scenes of Indian life. In the very beginning we have a chance to look into Jayamma's kitchen. It is a typical Indian kitchen. A blackened range runs along one wall, with firewood and charcoal stacked at the end. Jayamma is fanning a slow fire over which a brass vessel is simmering. Apu's house is very small and overcrowded.

When Ravi goes to the market he see a small cluster of people around the ice-fruit stand, mostly children without the money to buy. They have temptation for coloured syrup bottles. Along the sea-side also we may see hungry and able-bodied children.

We also see crowded cinema-halls and people busy in eating and drinking so many things--tea, coffee, cola, monkey nuts, ice-cream, pakora, karabandi etc.

In India generally the people have a bad opinion about police. It is noted for its cruelly. Ravi shivers at the thought of the people. They are "brutes and become devils 
when they put on their uniforms, the bigger ones in boots that they brought down so smartly on bare flinching toes." In the novel we also come to know about bazaar girls who are two a penny, they are perfectly shameless. Damodar and Ravi knew the girls, "who scarcely bothered to draw the cloth of their saris over their breasts; or who were to be seen riding in rickshaws at night on the Marina between Mylapore and the Fort, hidden behind grimy white drapes in perverted semblance of the habit of nun.

\section{CONCLUSION}

Kamala Markandaya is wonderfully accurate because of her amazing acquaintance with the rural and urban life of southern part of India. She is the most gifted woman novelist. She portrayed gloomy economic picture in her novels. Her prime concern is to focus our attention on the problems such as poverty and substandard living of the poor under privileged people, their untold sufferings because of the control of Indian Economy by the rich privileged class, the exploitation of labour and peasants lay the land owners and the balk breaking impact of industrialization on rural economy. The aforesaid analysis bears testimony to the fact that the novel A Handful of Rice presents a lively true picture of Indian Society.

\section{REFERENCES}

[1] Arya, Sushma. New Concerns. Voice in Indian Writing in English, ed., ShaliniSikka. Macmillan India, 2006.

[2] A Handful of Rice (Orient Paperback), pp.155-156.

[3] A Handful of Rice (Orient Paperback, 1966), p.12

[4] Bhatnagar, A.K. Kamala Markandaya: A Critical Spectrum. New Delhi: Atlantic Publishers, 2002

[5] Birkland,J.(1993).Ecofeminism: Linking Theory and Practice, in Gaard, G.Edi. Ecofeminism: Women, Animals and Nature. Philadelphia: Temple University Press.

[6] H.M.Williams, Indo-Anglian Literature (1800-1970)-A Survey, p.54

[7] Iyengar, K.R.Srnivasa, Indian Writing in English, New Delhi: Ashish Publishing House, 1993.Print.

[8] P.S. Chauhan, "Kamala Markandaya: Sense and Sensibility", The Literary Criterion, vol.XII, Nos.2-3.

[9] V.A. Shahane, "Indo-English Fiction and Question of Form". The JIWE (July, 1974), p.35. 